\title{
The Common Law, Labor Law, and Reality: A Response to Professor Epstein
}

\author{
Julius G. Getman† and Thomas C. Kohler††
}

Professor Epstein claims to have undertaken serious criticism and review of the American system of labor relations as it has been structured by two pieces of New Deal era legislation, the Norris-LaGuardia Act and the National Labor Relations Act. ${ }^{1}$ Such a work by a scholar of Epstein's stature could be of great value to such diverse disciplines as law, economics, sociology, industrial relations, political science, and psychology. To be worthy of its subject, such a study would involve an inquiry of tremendous empirical scope and raise the most difficult of methodological problems. How should one evaluate a process that has undergone incremental but constant change over the past forty-five years? By what standards should the efficacy of current labor laws be judged? Are basic democratic principles applicable to the workplace, and if so, to what extent should workers be afforded a voice in "managerial" determinations? Should models of worker participation in decisionmaking other than that sanctioned by the National Labor Relations Act be permitted, and if so, of what type ?2 ${ }^{2}$ These are important, interesting and difficult questions. Professor Epstein, however, avoids them entirely by a breathtakingly simple device: He takes the "common law" (in its late nineteenth-century form) as the appropriate "benchmark" against which to judge "modern statutory schemes."3 Thus, he never answers the questions a genuine critical evaluation would have to address, i.e., how have the labor laws worked? Have they helped or hindered American workers and the economy, and in what ways? Have they promoted productivity and industrial peace? Are they consistent with the democratic principles that form the framework of our system of government? What conclusions can be drawn and applied from the extensive transnational research that has already been conducted? In-

+ William K. Townsend Professor, Yale Law School.

t† Assistant Professor of Law, Boston College Law School.

1. Epstein, A Common Law for Labor Relations: A Critique of the New Deal Labor Legislation, 92 YALE L.J. 1357, 1357 (1983).

2. For two empirical studies of the effects of unionization, see R. FREEMAN \& J. MEDOFF, WHAT Do UNIONS Do? (1984); S. SlichteR, J. HEALY \& E. LIVERNASH, THE IMPACT OF COlleCTIVE BARGAINING ON MANAGEMENT (1967). For an analysis of alternative schemes of worker participation in management, see Kohler, Models of Worker Participation: The Uncertain Significance of Section 8(a) (2) (forthcoming).

3. Epstein, supra note 1, at 1359. 
stead, he comes to the not very remarkable conclusion that statutes avowedly designed to replace the common law, limit the market and do away with the use of contract by employers as a device to prevent worker selforganization are not consistent with the libertarian political theories, laissez-faire economics, and common law doctrines concerning the employment relationship and property rights that they replaced. In short, Professor Epstein's work does not contribute in any way to our existing store of knowledge about labor law. It sheds no light on the reality of labor relations, nor does it contribute anything to our understanding of the impact of labor law on society. Given the antiquated nature of his methodology, it is not surprising that Professor Epstein reiterates many of the same propositions, syllogisms and rationalizations of those who opposed the enactment of the NLRA and the Norris-LaGuardia Act in the first place, and without any newer evidence." As such, Professor Epstein's Article is representative of a growing but lamentable tendency in the legal literature to comment critically on areas in which the author has no expertise, using as a measure axioms formulated in vacuo and without regard to observed actualities.

Given his argument's anachronistic ring, it is interesting that Professor Epstein claims to have analyzed his topic in light of "recent advances both in general legal theory and in law and economics."' Prominent among the recent sources thus cited are several of his own earlier writings making similar forays into other fields of law, or analyzing rights from a libertarian perspective. His discussion of the common law governing the employment relationship relies heavily on English cases and commentaries that are no more recent than the eighteenth and nineteenth century. There is only one citation to modern industrial relations research and none to the findings of labor economists. Similarly absent is any discussion of the ac-

4. See National LAWYers COMMITTEe OF THE AMERICAN LiberTy LEAGUE, REPORT ON THE CONSTITUTIONALITY OF THE NATIONAL LABOR RELATIONS ACT (1935). The noted labor historian, Irving Bernstein, has written that

The du Ponts, with Sloan [Alfred P., Jr., the President of General Motors] . . . had been the principal founders and bankrollers of the American Liberty League, the voice of political and economic reaction in the mid-thirties. Its publications, "lavishly printed and widely circulated," as Arthur M. Schlesinger, Jr. has written, "depicted the United States on the verge of socialism, bankruptcy, and tyranny."

I. BERNSTEIN, TURbULENT YeARS: A HistORY OF THE AMERICAN WORKER, 1933-1941, at 515 (1970).

Professor Epstein's precursors, however, are much older than the Liberty League. For example, in 1835, Dr. Andrew Ure condemned combinations of workers which he stated interfered with the freedom of workers to offer their services to employers. A. URE, PHILOSOPHY OF MANUFACTURERS (London 1835). (Ure contended that organizations of workers were the product of agitators, who incited workers to violence and crime). Ure was an early apologist for the conditions brought about by industrialization. One of the goals of Ure's work was to demonstrate that child labor was not the cruel and inhumane thing reformers argued it to be. See R. BENDIX, WORK AND AUTHORITY IN INDUSTRY 89-91 (1956).

5. Epstein, supra note 1, at 1358. 
tual state of the common law at the time of the passage of the NLRA or the Norris-LaGuardia Act, or citation to empirical studies investigating the impact of law on reality. Discussion of or reference to the work of scholars in other disciplines concerning the impact of collective bargaining and employee self-organization on society is also wanting. Indeed, Professor Epstein abjures the need to discuss reality at all and at base rests his "investigation" on contractarian notions of rights in a mythic world of actors in the "original position"7 (whose trades, evidently, are supposed to bind us still).

It is not surprising that Professor Epstein would have us return to the legal order for labor relations that existed a half-century and more ago since he shares the values of those who established and maintained it. What does surprise is his apparent belief that the common law ordering of industrial relations was adequate at the time, or that it would prove efficacious in any manner today.

Common law notions about the employment relationship grew out of the law of domestic relations, ${ }^{8}$ and revealingly, leading commentators continued to treat the law governing employment relations (i.e., master and servant) as a part of that field until the early years of the twentieth century. ${ }^{-}$Treatises on the law of domestic relations thus continued to be the chief repository of commentary on employment law until well after the century's turn. As late as 1889 , for example, one leading treatise on domestic relations law, in its treatment of the master-servant relationship (which comprises roughly one-third of the treatise's content), defined servant as

persons commonly known in popular speech as workmen or employees. . . . In this class are included day laborers, factory operatives, miners, colliers, and numerous others, of whom nothing more definite can be said than that they are hired to perform services of a somewhat unambitious character. ${ }^{10}$

That modern forms of industrial organization had, by the last quarter of the nineteenth century, long outstripped the almost feudal premises of a

6. Id. at 1358.

7. Id. at 1364 .

8. In his analytic scheme of the common law, Blackstone grouped master and servant, husband and wife, and parent and child under The Law of Persons, characterizing these as "[t]he three great relations in private life." 1 W. BLACKSTONE, COMMENTARIES 410 (1979).

9. See, e.g., I. BROWNE, ELEMENTS OF THE LAW OF DOMESTIC RELATIONS AND OF EMPLOYER AND EMPLOYED (2d ed. 1890); E. PECK, THE LAW OF PERSONS OR DOMESTIC RELATIONS (1913); J. SCHOULER, A TREATISE ON THE LAW OF THE DOMESTIC RELATIONS: EMBRACING HUSBAND AND WIFE, PARENT AND CHILD, GuARDIAN AND WARD, INFANCY, AND MASTER AND SERVANT (4th ed. 1889).

10. J. SCHOULER, supra note 9, at 691-92. 
personal and ongoing relationship between the employer and employee on which the common law model rested was clear. The sudden appearance of the employment-at-will doctrine in the last quarter of the nineteenth century reflected the legal response to the growth of industrialization. Previously, the common law of employment in England and the United States had two well-established features: Employment was presumed to be for a period certain, the length of which was fixed by custom, and the employment relationship was terminable only for "reasonable cause" and upon the deliverance of customary and reasonable notice. ${ }^{11}$ In contrast, the new rule presumed that employment of no fixed duration was freely terminable at the will of either party. The new rule's appearance, of course, was concomitant with the phenomenal growth of the large industrial organization which so affected and characterized this era. ${ }^{12}$ Unlike the small, owner-operated shops and factories it displaced, the new industrial organization was not dependent on the skilled artisan for its successful and continued existence. Mass production techniques increasingly made skills obsolete and workers fungible. Industry now depended upon the availability of a large pool of workers who could be hired and discharged according to the demand for production. The at-will doctrine more accurately mirrored and fit the needs and behavior of industry; hence, it quickly came to replace the prior common law rules governing the employment relationship.

The at-will doctrine thus began to shift employment law away from the law of domestic relations and to shift the intellectual framework within which the relationship was conceptualized from one based on a relationship status to one structured by contract doctrine. Not surprisingly, this change occurred at the height of the success of formalized notions of contract in the courts, which ironically enough coincided with the beginnings of public and legislative rejection of the premises of a laissez-faire market society. ${ }^{18}$ These contract notions justified the at-will doctrine on the basis

11. M. Glendon, The New Family and the New Property 148-49 (1981). Professor Glendon also observes that the law of France, Germany and Sweden during this period was similar. Id. Blackstone notes that, unless otherwise agreed, a quarter's notice was required before discharging a servant, and that a general hiring was presumed to be for the period of one year. $1 \mathrm{~W}$. BLACKSTONE, supra note 8 , at $413-14$.

12. Some figures help remind one how great this growth was, and how fast it developed. For example, from 252,000 in 1869 , the number of manufacturing establishments in the U.S. increased to 512,000 in 1899; the number of factory wage earners from 2.1 to 5.3 million, and the value product of manufacturers from $\$ 3.4$ to $\$ 13.0$ billion. M. DERBER, THE AMERICAN IDEA OF INDUSTRIAL DEMOCRACY, 1865-1965, at 30-31 (1970).

13. See L. Friedman, Contract LaW in AmErica: A SOCial and Economic Case STUdY 17-26 (1965); M. GLENDON, supra note 11, at 148-49; J. HURST, LAW AND THE CoNDITIONS OF FREEDOM IN THE NINETEENTH-CENTURY UNITED STATES 71-78 (1975).

Interestingly, as Professor Glendon points out, the at-will doctrine "appeared almost simultaneously, as if written by an invisible hand, in the master-servant law of England, France, Germany, Sweden and the United States." M. GLENDON, supra note 11 , at 148 . In the United States, the 
of mutuality, i.e., that workers were as free as employers to terminate the relationship. ${ }^{14}$ As one noted commentator has observed, this shift in the conceptualization of the relationship exchanged "the older notions of protection and loyalty for a new legitimating fiction-freedom of contract."15 As is true of most common law doctrines in the process of evolution, however, the law governing the employment relationship continued to carry with it some vestiges of the domestic relations concepts from which it had grown. The most significant of these was the idea of a personal relationship between the employer and employee. This notion was seized upon by the courts as they tried to fit the employment relationship into the intellectual framework that they had worked out for contract law over the preceding fifty or so years. The idea of a personal relationship was a handy one, for it fit well the notions of bargaining, a meeting of the minds, and voluntary association that the contractual elements of offer, acceptance and assent encapsulate. Another notion that was carried over from the domestic relations framework was the employee's duty of loyalty to the employer. Significantly, however, the employer's reciprocal duty of protection that the law once imposed was lost in the process of the new rule's evolution. ${ }^{16}$

It is important to remember in considering Professor Epstein's arguments and the development of the common law ordering of the employment relationship that the most significant developments in the fields of contract law and theory occurred during roughly the first half of the nineteenth century. As Lawrence Friedman has observed, as late as the publication of the Commentaries in the latter half of the eighteenth century, Blackstone devoted but a few pages to contract law. In contrast, the law of property occupied nearly an entire volume of the four-volume work. ${ }^{17}$

doctrine was initially announced by H.G. Wood in his treatise on Master-Servant Law, published in 1877. Significantly, this was the first treatise in the United States to be devoted entirely to the subject. Wood noted in the Preface that the topic had previously been treated as part of domestic relations law. Although Wood stated that in the U.S., the at-will rule was "inflexible" and universal, the cases he cited are inapposite. H. WOOD, A TREATISE ON THE LAW OF MASTER AND SERVANT $\$ \S 134,272$ (1877). Nevertheless, Wood's rule was quickly accepted by the courts.

14. See Adair v. United States, 208 U.S. 161, 174-75 (1908) ("[T]he right of the employee to quit the service of the employer, for whatever reason, is the sarne as the right of the employer, for whatever reason, to dispense with the services of such employé.").

15. M. GLENDON, supra note 11 , at 150 .

16. See id. at 143-50. There are many examples of the erosion of this duty, from the cessation of a master's obligation to oversee the moral and physical well-being of his servants, to the growth of tort doctrines such as assumption of risk and the fellow servant rule that had the effect of isolating employers from liability for workplace accidents. See Green, Assumed Risk as a Defense, 22 LA. L. REV. 77, 83-84 (1961).

These developments were all part of a larger trend toward the formulation of new ideologies tailored to fit the rise of industrialization and an entrepreneurial group. See R. BENDIX, supra note 4, at 73-117.

17. See, e.g., L. Friedman, A HiStORY OF AMERICAN LAW 244 (1973); L. FriedMan, supra note 13 , at $17-18$. 
The growth of contract law was, of course, coeval with the disintegration of a relationally ordered society and the appearance and growth of an entrepreneurial, market-centered economy. Contract, unlike other developed areas of the law, such as property and domestic relations, provided a ready vehicle for arranging private, impersonal market relationships. The elements of contract theory - that parties are individual economic actors who enjoy complete freedom of mobility and decision ${ }^{18}$ - were congenial to the people of an era who, as J. Willard Hurst has said, desired the legal order to "protect and promote the release of individual creative energy to the greatest extent compatible with the broad sharing of opportunity for such expression."19

The growth of large industrial and financial organizations in the latter half of the nineteenth century, along with the appearance and growth of a subsidiary rentier interest, reflected the substantial change in capital distribution that had occurred since the start of the century. "This distribution," Professor Hurst has observed, "concentrated unprecedented power of decision in private hands, first in the railroads, then in heavy industry and in investment banking houses and life insurance companies." ${ }^{\text {,20 }}$ Further, the law's provision of "a range of flexible contract and association devices, notably the corporation and the procedures of large-scale finance" resulted in:

the enormous expansion of practical compulsion imposed on strangers to contracts or associations, as commercial and industrial corporations and investment bankers reached out to occupy the multi-state markets whose availability the law had guaranteed. Economic growth tied the lives of an increasing proportion of people to the market and the division of labor; they were either wage or salary earners, or small producers or traders in specialized ranges of goods or services. Theoretically buyers consent to the practical compulsions of the market in which they buy; if they do not consent, they stay out. But men who find their whole livelihood in the market are too vulnerable to stay out. ${ }^{21}$

The upshot of these developments was a restriction of the breadth of practical choices and equality of opportunity that had once been available to individuals. The resulting sense of personal helplessness and inability to control events, Hurst observes, led to the preoccupation with methods to redress the balance of power that so marked the last quarter of the cen-

18. L. FRIEDMAN, supra note 13 , at 21 .

19. J. HURST, supra note 13 , at 6 .

20. Id. at 78 .

21. Id. at 75 . 
tury. The release of energy theme now came to be expressed through associations. The unprecedented formation of disciplined groups organized around specific programs, such as the Farmers' Alliance, the Knights of Labor, and the American Federation of Labor were part of this response. ${ }^{22}$ Contract, which had earlier served as the vehicle for the release of individual energy, proved "inherently too limited an institution to serve this need" in a society increasingly dominated by large industrial and financial organizations. ${ }^{23}$

It was in this milieu that the "new" common law model of employment was launched. With attributes from both domestic relations and contracts, the model of the employment relationship was precariously and uncomfortably perched between two conceptual frameworks, both of which themselves were becoming anachronistic. The general social and industrial unrest, strikes, demonstrations calling for the legal recognition of workers' rights to organize, and the rapid growth of unions and other organizations devoted to furthering workers' interests that attended the last quarter of the nineteenth and the early decades of the twentieth centuries were all symptomatic of the incapacity of the common law to deal with patterns of modern social organization. By the 1880's, the search for a new model by which to order the employment relationship had become a societal preoccupation and would remain one until the advent of the New Deal era. Detailing the course of this search and the development of the various schemes put forward as alternatives far exceeds the scope of this Comment. ${ }^{24}$ It is sufficient for present purposes to note that by the end of the nineteenth century, collective bargaining had surpassed contending models such as producer cooperatives, utopian communities, "industrial partnership plans" (based on various profit-sharing arrangements) and calls for the reformation of government along socialist lines as the predominant alternative scheme for the ordering of the employment relationship.

That the collective bargaining model prevailed over its rivals is predominantly attributable to its congruence with the values and patterns of life in American society. Unions were organized as a response to the organization of capital and employers that had been made possible through the pliable contract and association devices the law had devel-

22. Id. at 85. Other such groups mentioned by Professor Hurst include the Grange, the Grand Army of the Republic, the American Woman Suffrage Association and the National Woman Suffrage Association, the Women's Christian Temperance Union, the Anti-Saloon League, and the National Civil Service Reform League. Trade associations and business lobby groups, Hurst notes, also took more formal shape in these years. Among those formed during this period were the National Potters Association, the Stove Founders National Defense Association, and the National Association of Manufacturers. Id.

23. Id. at $75-76$.

24. An admirable study of this search is contained in M. DERBER, supra note 12; see also Kohler, supra note 2 . 
oped. Like other program groups, the goal of unions was to redress an imbalance of power; here, the imbalance that exists between an individual employee and the entity for which he or she works. In this respect, unions mirrored the industrial organizations that employed their members. As the latter assembled to take advantage of the amplified power that the combination of capital and other resources provided, so workers sought, through association, to obtain bargaining strength in settling the terms and conditions of their employment. The idea of the collective agreement was also consistent with the contract notions that had been developed over the course of the century. The terms of the employment agreement would continue to be privately set. Reflecting the reality of the time, however, they would be set through negotiation between two organized entities, and not between an individual and an organization (which, of course, usually results in no bargaining whatever because the latter can most often state the terms on a take-it-or-leave-it basis). Further, unlike many of its rivals, the collective bargaining model entailed no change in social structure. Unions sought neither to reorganize the economy nor to displace management in the operation of industry. ${ }^{25}$ As Mine Workers' president John Mitchell stated in 1903, unionism "stands for the liberty of workingmen to arrange their own lives and to contract jointly for the manner in which they shall be spent in mine or factory." ${ }^{26}$ Unions, then, like the other program groups that emerged contemporaneously with them, became the vehicles through which, in Hurst's words, one would "mobilize group power in behalf of individual status"27 in a society where, in the market and elsewhere, power was increasingly passing away from individuals to organizations.

The deficiency in the common law as it emerged was that it provided the employer techniques for rejecting unions regardless of the wishes of the employees. Under this system, an employer could discipline or blacklist union supporters, refuse to bargain without regard to employee senti-

25.

Collective bargaining in industry does not imply that wage earners shall assume control of industry, or resonsibility for financial management. It proposes that the employees shall have the right to organize and to deal with the employer through selected representatives as to wages and working conditions.

Among the matters that properly come within the scope of collective bargaining are ivages, hours of labor, conditions and relations of employment, the sanitary conditions of the plant, safety and comfort regulations and such other factors as would add to the health, safety and comfort of the employees, resulting in the mutual advantage of both employers and employees. But there is no belief held in the trades unions that its [sic] members shall control the plant or usurp the rights of the owners.

S. GOMPERS, LABOR AND THE EMPLOYER 286 (1920), quoted in M. DERBER, supra note 12, at 127. For a further elucidation of the role of unions as conceived of by the AFL, see Gompers, What I Should Do If I Were An Employer, 27 AMERICAN FEDERATIONALIST 351 (1920).

26. J. Mitchell, ORganized LabOR (1903), quoted in M. Derber, supra note 12, at 123-24.

27. J. HURST, supra note 13 , at 86 . 
ment, and obtain court injunctions against union organizing if some of his employees were subject to yellow dog clauses. Much of Professor Epstein's article is devoted to a defense of the yellow dog device. This defense is supported in part by an indirect attack on unions and collective bargaining, and in part by the contention that such contracts should be seen not as employer coercion but rather as an expression of the employee's freedom of contract; a technique by which employees, for an economic premium, exchange their right to join a union. The latter argument ignores the fact that if employees want to trade their right to bargain collectively (and many do), they are in a much stronger position when they have a legal right to secure union representation if they are dissatisfied with what the employer has provided or what they believe the employer will provide. As long as employees have the right to unionize, non-union employers are motivated to pay union scale or above, and employees are in a position to monitor the indirect promises which are a regular feature of union organizing campaigns. What the combination of the yellow dog device and the injunction did was to make it possible for an employer to get the same degree of assurance against unionization for little or nothing. Thus the yellow dog device, like much of the common law scheme that Epstein urges, makes good policy only if one is in favor of allowing employers the legal option of operating on a non-union basis if they feel strongly enough about it to either battle with or pay their employees a small premium for the privilege. During the period in which employers had this choice they exercised it so fiercely and were met by such determined extra-legal resistance that almost no one was satisfied with the law to which Professor Epstein would have us return.

Recognition among policymakers of the inadequacies of the common law ordering of the employment relationship as it stood in the last quarter of the nineteenth century was not long in coming. Within five years of the end of the Civil War, both houses of Congress had established Committees on Labor, ${ }^{28}$ and in 1878 the first full-scale congressional inquiry into labor relations was undertaken through a Select Committee of the House. ${ }^{29}$ Continuing unrest and disputes led to other inquiries by various House and Senate committees, ${ }^{30}$ the creation of the Bureau of Labor (1884), ${ }^{31}$

28. The House Committee on Education and Labor was established in 1867; the Senate Committee on Education and Labor was established in 1870. U.S. DEP'T. OF LABOR, THE ANVIL AND THE Plow: A History OF THE UNITED STATES DEPARTMENT OF LABOR 275 (1963).

29. M. DERBER, supra note 12 , at 83 .

30. See, e.g., SElect COMMITTEe ON Existing Labor Problems, InVEstigation of Labor Troubles In Missouri, ARKanSaS, KanSAS, TEXAS, AND IllinoIS, H.R. Rep. No. 4174, 49th Cong., 2d Sess. (1887); SENATE COMMITTEE ON EDUCATION AND LABOR, REPORT OF THE COMMITTEE OF THE SENATE UPON THE RELATIONS BETWEEN LABOR AND CAPITAL AND TESTIMONY TAKEN BY THE COMMITTEE, 48th Cong. (1883).

31. Act of June 27,1884 , ch. 127, 23 Stat. 60. The Bureau was established as a division of the 
whose tasks included the collection of information about labor relations and disputes, and the appointment by President Cleveland in 1894 of the U.S. Strike Commission, ${ }^{32}$ which was charged with investigating the causes of, and formulating solutions to, labor relation problems on the railroads. Interestingly, among other things, the Commission recommended federal legislation to outlaw the yellow dog device (noting that such legislation had already been enacted in several states) and it urged employers to recognize the labor organizations to which their employees belonged. ${ }^{33}$ The work and thoughts of these earlier bodies was capped by the creation of the U.S. Industrial Commission in 1898. ${ }^{34}$ The Commission's eighteen members were jointly appointed by President McKinley and Congress, and their investigation was the most extensive of any yet conducted. The Commission heard testimony from nearly seven hundred witnesses, and collected extensive documentary and statistical information. ${ }^{35}$ It was assisted in its work by a large staff that included such noted economists as John R. Commons. The Commission recommended the enactment and extension of a variety of legislative reforms that would promote the practice of collective bargaining. "[E]very facility," the Commission stated, "should be given labor to organize if it desires. . ." chief advantage to be obtained from collective bargaining, the Committee opined, was that through its practice, "each side obtains a better understanding of the actual state of the industry, of the conditions which confront the other side, and of the motives which influence it." 37 "Most strikes and lockouts would not occur," stated the Committee, "if each party understood exactly the position of the other." ${ }^{\text {"38 }}$ The Committee also

Department of the Interior; in 1888, legislation was passed that gave it independent status as the Department of Labor. The Department was under the direction of a commissioner who lacked cabinet status, but who reported directly to the President. Act of June 13, 1888, ch. 389, 25 Stat. 182. The Department gained cabinet status with the enactment of the Sulzer bill in 1913, which President Taft signed on his last day in office.

32. The Commission was appointed by President Cleveland as a result of the Pullman Strike of 1894, under authority of an Act permitting the President to appoint such a body for the purpose of inquiring into and settling labor disputes on the railroads. Act of October 1, 1888, ch. 1063, § 6, 25 Stat. 501. For a brief description of the events surrounding Pullman, see P. TAFT, ORGANIZED LABOR IN AMERICAN HistORY 147-58 (1964). See also W. CARWARdine, ThE PUllMAN STRIKE (1894) (a contemporary account); A. LINDSEY, THE PULLMAN STRIKE (1942); THE PULLMAN BOYCOTT OF 1894: THE PROBLEMS OF FEDERAL INTERVENTION (E. Warne ed. 1955).

33. UNITED STATES STRIKE COMMISSION, REPORT ON THE GHICAgO STRIKE OF JUNE-JULY, 1894 LIV, S. EXEC. DOC. No. 7, 53d Cong., 3d Sess. (1895).

34. Act of June 18, 1898, ch. 466,30 Stat. 476.

35. The testimony before, findings of, and special studies conducted by the Commission are contained in nineteen volumes; the Commission pursued its work from 1898 to 1902.

36. U.S. INDUSTRIAL COMMISSION, 5 REPORT OF THE INDUSTRIAL COMMISSION ON LABOR LEGISLATION 8, H.R. DOC. NO. 95, 56th Cong., 1st Sess. (1900).

37. U.S. INDUSTRIAL COMMISSION, FINAL REPORT OF THE INDUSTRIAL COMMISSION 844, H.R. DOC. No. 380, 57th Cong., 1st Sess. (1902).

38. Id. 
observed that bargaining would remove "the occasions of minor misunderstandings" and would facilitate their correction. "A large proportion of labor disputes," the Committee reminded, "originate in very unimportant matters." "In the absence of the machinery and the attitude of peaceful discussion," noted the Committee, "misunderstanding grows into bitterness, and too often" a strike or lockout results. ${ }^{38}$ The third advantage bargaining offered, stated the Committee, was that its successes were cumulative. "The practice of meeting together," the Committee commented, "constantly increased mutual understanding and mutual respect, between employers and employees." ${ }^{40}$ Fifteen years later, the members of the U.S. Commission on Industrial Relations, who had been appointed by Congress to study "the underlying causes of dissatisfaction in the industrial situation,"41 again recommended extensive reformations of the law governing relations between workers and employers, and endorsed the concept of collective bargaining. ${ }^{42}$

Significantly, participants in the search for a new model by which to order the employment relationship were not limited to social reformers, union activists, academics, and members of congressional panels, but included management itself. Management's objectives in this endeavor were twofold. ${ }^{43}$ The first was to discover new methods of group dealing that would improve communication with employees, thereby reducing friction between management and workers and in turn, securing both the willing cooperation of the latter with management's directives and identity with its goals. The second was to develop a model that could compete successfully with collective bargaining; ${ }^{44}$ ironically, after the turn of the century, and into the 1920's, union membership continued to grow despite the legal obstacles placed in its way by the courts. ${ }^{45}$ Tellingly, of the various schemes with which management experimented, so-called employee representation plans, or company unions, became the dominant employer alternative. As their sobriquet implies, these plans shared many similarities with collective bargaining. They provided employees with a means of having their voices heard concerning company policies and they often provided for grievance machinery, albeit of a much more limited scope than

39. Id.

40. Id.

41. Act of Aug. 23, 1912, ch. 351, 37 Stat. 415.

42. See U.S. COMmisSion ON INDUSTRIal Relations, Final REPORT OF the COMMISSION ON INDUSTRIAL RELATIONS (1915).

43. For a study of the unfolding ideology of American management in this period, see R. BENDIX, supra note 4 , at $254-87$.

44. Concerning the development of these alternative plans, see Kohler, supra note 2, and sources cited therein.

45. In 1897 (at the close of a sharp depression) unions had under 500,000 members; by 1920, over 5 million workers were union members. M. DERBER, supra note 12, at 173 . 
that usually furnished through collective bargaining. The chief and crucial difference between collective bargaining and the employers' alternative, not surprisingly, was the degree of control the employer exercised over the "representation plan" and the limitation of the plan's coverage to the workers of one employer. ${ }^{46}$ For purposes of the present discussion, however, the key thing to be noticed is that management, like other sectors of society, had increasingly found the common law ordering of the employment relationship unworkable and unsatisfactory and that, by the 1920's, the leading substitute model that management had come to employ bore a striking similarity to collective bargaining. Significantly, both the growth in union membership and the use of "representation plans" occurred in spite of the fact that management was legally protected from any duty to bargain with employees or their bargaining representatives.

By the eve of the New Deal era, then, the model of the employment relationship that the common law had devised nearly fifty years before had become almost irrelevant. The actions and practices of both employees and employers had grown around and over it, much as a tree surrounds barbed wire stretched about its trunk. The model's chief use was to provide the courts with an intellectual framework for the denial of the associational rights to employees that the law had guaranteed to employers as a fundamental right.

Not surprisingly, the common law of the employment relationship of fifty years ago no more describes current management practices of large businesses than it reflected those of the 1930's. Contemporary management theory and practice emphasizes the involvement of workers in managerial decisionmaking. Like the pre-NLRA era, the management-oriented alternatives to collective bargaining have adopted many of the latter's features; their chief distinction, as in the past, lies in the control management retains over participation schemes in an unorganized setting. More significant, perhaps, is the fact that the common law governing the employment relationship has itself undergone great changes over the last decade, and bears only slight resemblance to the model for which Professor Epstein longs. It now affords workers at least some of the substantive protection once available only through self-organization, and the trend is decidedly in the direction of broadening the protections of employees' interests in the employment relationship. ${ }^{47}$ Professor Epstein would reverse all of this development without empirical investigation, and return to an order which had largely been dismissed by all sides because that order conforms more closely to his theoretical preferences.

46. A thorough study of various representation plans is contained in TWENTIETH CENTURY FUND, INC., LABOR AND THE GOVERNMENT (1935). See also supra note 44.

47. See M. GLENDON, supra note 11, at 143-205. 
In light of this development, then, Professor Epstein's assertion that "traditional common law principles provide a benchmark, both theoretical and historical" against which to judge the Norris-LaGuardia Act and the National Labor Relations Act is a curious one. Common law rules, Blackstone said, derive their weight and authority from their usage from a "time whereof the memory of man runneth not to the contrary." 48 As the foregoing discussion indicates, contrary to what Professor Epstein suggests, the ordering of the employment relationship along the lines of contractual theory is not practice "used time out of mind," but is instead a fairly recent innovation. Until the late 1870's, employment was treated as a status relationship, and, as Mary Ann Glendon has shown, ${ }^{48}$ the common law has since come full circle and is once again according to the relationship many elements of a status. Hence, from an historical standpoint, the common law ordering of employment of the late nineteenth century can be regarded as a fairly short-lived anomaly rather than a longstanding and tested method of ordering.

Professor Epstein, of course, has additionally asserted that the late nineteenth century ordering of employment provides a proper theoretical touchstone against which to judge "modern statutory schemes," because they favor "limited government" and allow "the maximization of private autonomy." These, too, are curious claims.

The reign of the common law model favored by Professor Epstein was hardly one marked by a lack of governmental intervention, as names like Coeur d'Alene, Pullman, and McKeesport recall. Further, the use of the injunction as a device to break strikes, and after the Hitchman Coapo decision, as a tool to enforce yellow dog clauses entailed extensive involvement of the judiciary in labor relations matters. In his well-known study, The Government in Labor Disputes, Edwin Witte found that in the halfcentury between 1880 and 1930, state and federal courts issued 1,845 injunctions on employer's applications in labor disputes. ${ }^{51}$ Interestingly, Witte finds that prior to 1880 , American courts issued no injunctions in matters involving labor relations, but that the number of such orders increased steadily with each decade thereafter. ${ }^{\mathbf{b 2}}$ Thus, Witte's research revealed the issuance of 28 such orders between 1880 and 1890. In contrast, he found that 921 labor injunctions were granted in the decade $1920-1930 .{ }^{53}$ Of these injunctions, sixty were to enforce yellow dog agree-

48. 1 W. BLACKSTONE, supra note 8 , at 67 .

49. M. GLENDON, supra note 11.

50. For a meticulous dissection and criticism of the majority's opinion in the Hitchman decision, see Cook, Privileges of Labor Unions in the Struggle for Life, 27 YALE L.J. 779 (1918).

51. E. WITTE, THE GOVERNMENT IN LABOR DISPUTES 84 (1969).

52. Id. at 83-84.

53. As Professor Irving Bernstein has observed, this figure assumes "added meaning when viewed 
ments. ${ }^{54}$ Indeed, the judiciary's involvement in labor matters through the use of its equity powers became so extensive that calls for the limitation of the courts' authority to issue injunctions in such disputes came not only from labor and academics, but also from leaders of the bar and conservative political figures. ${ }^{56}$ Among such persons were S.S. Gregory, ${ }^{56}$ a president of the American Bar Association, and Senator George Wharton Pepper of Pennsylvania. ${ }^{57}$ Much of these commentators' concern centered on the proper role of the courts in such disputes, where the outcome could largely depend on the decision of an unelected official. "Must we not," asked Pepper, "confine the courts to the sphere in which the creators of our constitutional system intended them to live . . ?" then, the rise of court intervention parallels the growth of large industrial organizations. As the common law model became more inadequate, the resort to state intervention became more frequent.

It should be recalled in discussing nineteenth century notions of contractual freedom that this method of public ordering places great state power in private hands. The role of government in a regime of "freedom of contract" is to enforce private agreements at the instance of a promisee. ${ }^{59}$ As Max Weber so early pointed out, the phrase "freedom of contract," though evocative, is misleading to the extent that it suggests an individual is free from domination by others. Its essential feature is not that persons are left unregulated to make agreements as they please, but rather, Weber observed, that their agreements will be enforced by the state, in favor of the promisee. ${ }^{60}$ This method of ordering thus does more than lend official backing to private transactions that have no necessary

against the fact that employers faced very few strikes" during this decade. I. BERNSTEIN, THE LEAN YEARS: A HISTORY OF THE AMERICAN WORKER, 1920-1933, at 200-01 (1960).

54. The latter figure, Witte points out, should not be undervalued. While injunctions to enforce yellow dog contracts comprised "less than 10 percent of the total injunctions during this period," Witte notes:

several of these writs were taken out by a large number of employers acting jointly. These, moreover, have been the most extensive of all injunctions in their provisions and remain in effect so long as the complainants continue to use individual non-union agreements. [After the Hitchman decision] [i]njunctions based on yellow-dog contracts now block all attempts to organize the coal miners throughout West Virginia; and there are a considerable number of scattered mines and manufacturing plants elsewhere which are protected against efforts at organization by injunctions issued some years since, now dormant, but likely to be revived should organizers put in an appearance.

E. WITTE, supra note 51 , at 224 (footnote omitted).

55. For an excellent summary of labors' treatment by the courts during the period 1920-33, see I. BERNSTEIN, supra note 53, at 190-243.

56. See S. Gregory, Address of the President, Annual Meeting of the American Bar Ass'n, 37 REP. OF THE A.B.A. 255, 264-71 (1912).

57. Pepper, Injunctions in Labor Disputes, 44 REP. OF THE A.B.A. 174 (1924).

58. Id. at 179 .

59. M. WEBER, ECONOMY AND SOCIETY 668-69 (1968); Rheinstein, Introduction to MAX WEBER ON LAW IN ECONOMY AND SOCIETY, at lx-lxi (1954).

60. M. WEBER, supra note 59 , at $99-100$. 
connection with an individual's freedom from domination; it acts, as Weber pointed out, to strengthen the positions of those who already have economic power over others. ${ }^{61}$

The model for which Epstein argues, as history shows, brought about the results Weber described. It did not, nor would it, afford in Hurst's words, the "release of individual creative energy to the greatest extent compatible with the broad sharing of opportunity for such expression." Indeed, as we have seen, it was when financial and industrial organizations became so dominant that they restricted the equality of opportunity available to individuals that program groups like unions began widespread formation.

Professor Epstein tacitly admits that his model would yield the results delineated by Weber. ${ }^{63}$ Hence, it is especially peculiar, given his goal of

\section{Id. at 729-31. Thus, as Weber states:}

The formal right of a worker to enter into any contract whatsoever with any employer whatsoever does not in practice represent for the employment seeker even the slightest freedom in the determination of his own conditions of work, and it does not guarantee him any influence on this process. It rather means, at least primarily, that the more powerful party in the market, i.e., normally the employer, has the possibility to set the terms, to offer the job "take it or leave it," and, given the normally more pressing economic need of the worker, to impose his terms upon him. The result of contractual freedom, then, is in the first place the opening of the opportunity to use, by the clever utilization of property ownership in the market, these resources without legal restraints as a means for the achievement of power over others. The parties interested in power in the market thus are also interested in such a legal order. Their interest is served particularly by the establishment of "legal empowerment rules." This type of rule does no more than create the framework for valid agreements which, under conditions of formal freedom, are officially available to all. Actually, however, they are accessible only to the owners of property and thus in effect support their very autonomy and power positions.

Id. at 729-30 (footnote omitted).

62. J. HURST, supra note 13 , at 6 .

63. Professor Epstein's only defense to this is an ipse dixit: "[T]hat most contracts are for the mutual benefit of both parties, regardless of their original endowments of wealth." Epstein, supra note 1, at 1360 . Weber, however, pointed out that:

The increasing significance of freedom of contract and, particularly, of enabling laws which leave everything to "free" agreement, implies a relative reduction of that kind of coercion which results from the threat of mandatory and prohibitory norms. Formally it represents, of course, a decrease of coercion. But it is also obvious how advantageous this state of affairs is to those who are economically in the position to make use of the empowerments. The exact extent to which the total amount of "freedom" within a given legal community is actually increased depends entirely upon the concrete economic order and especially upon the property distribution. In no case can it be simply deduced from the content of the law .... [c]oercion is exercised to a considerable extent by the private owners of the means of production and acquisition, to whom the law guarantees their property and whose power can thus manifest itself in the competitive struggle of the market. In this type of coercion the statement "coactus voluit"18s applies with peculiar force just because of the careful avoidance of the use of authoritarian forms. In the labor market, it is left to the "free" discretion of the parties to accept the conditions imposed by those who are economically stronger by virtue of the legal guaranty of their property.

183"Coactus voluit" (it is his wish, although coerced)-Romanist phrase to describe the situation of an individual who has engaged in a legal transaction under the influence of coercion, in contrast to the situation in which a person is used as the mere physical tool of another, for instance, where the latter forcibly grabs the former's hand and moves it so as to go through the 
maximizing personal autonomy, that he would put into employers' hands, through the legalization of the yellow dog device, the power effectively to determine whether employees should enjoy the same associational rights the law affords employers. It is perhaps at this point that the degree of state authority transferred to private hands under a "freedom of contract" regime is made most clear.

The appearance and extent of power that would be held by large industrial and financial organizations could hardly have been foreseen at the time that liberal economic theories first developed. Yet, even in 1776, Adam Smith observed that

We rarely hear ... of the combinations of masters, though frequently of those of workmen. But whoever imagines, upon this account, that masters rarely combine, is as ignorant of the world as of the subject. Masters are always and every where in a sort of tacit, but constant and uniform combination, not to raise the wages of labour above their actual rate. To violate this combination is every where a most unpopular action, and a sort of reproach to a master among his neighbors and equals. ${ }^{64}$

Smith noted, however, that when their employees organize themselves: "The masters upon these occasions . . . never cease to call aloud for the assistance of the civil magistrate, and the vigorous execution of those laws which have been enacted with so much severity against the combinations of servants, labourers, and journeymen." ${ }^{\prime 65}$

In summary, if the maximization of personal autonomy is his goal, it is difficult to perceive why Professor Epstein champions a return to the legal order of more than a half-century ago. As Weber recognized, ${ }^{66}$ such an order does not lead to greater autonomy, but rather to an ever-increasing restriction upon the freedom of individual action. ${ }^{67}$ This proclivity would

physical motions of writing a signature.

M. WEBER, supra note 59 , at 730-31, 752 .

64. A. SMITH, AN INQUIRY INTO THE NATURE AND CAUSES OF THE WEALTH OF NATIONS 75 (U. of Chicago Press ed. 1976). Concerning the appropriation and "misuse" of Smith's thought by apologists for capitalism as it developed in the nineteenth century, see A. LINDEMANN, A HISTORY OF EUROPEAN SOCIALISM 31-33 (1983).

It is interesting to compare the excerpt from Smith above with the following from the report of the U.S. Strike Commission, supra note 33 , at xlvii:

We also have employers who obstruct progress by perverting and misapplying the law of supply and demand, and who, while insisting upon individualism for workmen, demand that they shall be let alone to combine as they please and that society and all its forces shall protect them in their resulting contentions.

65. Id. at 75-76.

66. Weber's sudden and untimely death occurred in 1920. The first portions of Economy and Society appeared in 1921 .

67. As Weber stated:

The private enterprise system transforms into objects of "labor market transactions" even those 
be exacerbated by the re-legalization of the yellow dog device. It, of course, amplifies and cements the economic power enjoyed by employers under a "freedom of contract" regime by ensuring that employees will be able to combine their resources only upon the former's sufferance. ${ }^{68}$ In effect, the yellow dog device allows employers to sit on both sides of the table, by permitting them largely to determine and regulate the strength of employees' bargaining power. Reduced to its basics, Professor Epstein's model ensures that the more powerful party in the market will dictate the terms of employment, and that that party will be the employer.

Unfortunately, Professor Epstein leaves unexamined and apparently unappreciated the essence of collective bargaining: its function as a method through which employees and employers jointly establish a comprehensive scheme of industrial self-government. ${ }^{6 \theta}$ In David Feller's words, collective bargaining provides:

a system of law to govern matters much more important to the employee than those governed by most public law: his right to a job and to a promotion, the hours at which and the conditions under which he is required to work, his right to refuse or to share in the opportunity to work overtime, the length and scheduling of his vacations, and so forth. ${ }^{70}$

personal and authoritarian-hierarchical relations which actually exist in the capitalistic enterprise. While the authoritarian relationships are thus drained of all normal sentimental content, authoritarian constraint not only continues but, at least under certain circumstances, even increases. The more comprehensive the realm of structures whose existence depends in a specific way on "discipline," that of capitalist commercial establishments, the more relentlessly can authoritarian constraint be exercised within them, and the smaller will be the circle of those in whose hands the power to use this type of constraint is concentrated and who also hold the power to have such authority guaranteed to them by the legal order.

M. WEBER, supra note 59 , at 731 .

68. Professor Epstein's arguments would appear to permit employers nearly boundless ability to control the associational ties that their employees might form. For example, it appears that an employer could lawfully require, as a condition of employment, that an applicant agree to abjure certain religious practices or refrain from joining or assisting a given (or all) political parties. Like the choice between assenting to a yellow dog clause or remaining unemployed, under Professor Epstein's premises, one cannot argue that these choices are illusory because of economic inequality between the parties. Assuming that there is no use or threat of force involved, the only objection that can be interposed to the legal system's recognition of the validity of these clauses is that the applicant has a precontractual right to demand both political party membership and employment, or a precontractual right to engage in certain religious practices and employment. Assuming that the employer in question is a private person or entity, with no relation to the state, such rights would seem to exist only if, like the right to one's own person, they are recognized as being basic and inalienable. Significantly, no less a moral authority than the Pope, JOHN PAUL II, LABOREM EXERCENS (ON HUMAN WORK) $\$ 20$, at 48-49 (1981) and no less a political authority than President Reagan, N.Y. Times, Oct. 10, 1982, at 16, col. 1 (address in reaction to the banning of Solidarity by the Polish government on October 9 , 1982) have proclaimed that union membership is such a right.

69. The Supreme Court recognized this key aspect of collective bargaining in its landmark opinion in Steelworkers v. Warrior \& Gulf Navigation Co., 363 U.S. 574, 580 (1960) ("A collective bargaining agreement is an effort to erect a system of industrial self-government." Consequently, stated the Court, the agreement "is more than a contract; it is a generalized code . . . ." Id. at 578).

70. Feller, A General Theory of the Collective Bargaining Agreement, 61 CAL. L. REV. 663, 761 
The duty to bargain affords employees the opportunity to participate in the framing and administration of the terms and rules that govern the worker-employer relationship. ${ }^{71}$ This modification of the character of rulemaking and administration in the workplace from a unilateral and authoritarian process to one of bilateral consultation is the gist of collective bargaining as established by the National Labor Relations Act. ${ }^{72}$ It is this-the sharing of power-that underlies much of the resistance to the idea of collective bargaining, and to the Act itself.

Contrary to the impression that one might receive from Professor Epstein's description, a central principle of the American model of collective bargaining is the exclusion of government from the parties' relationship. A noteworthy feature of the framework the Act establishes for the creation of this private system of law, and one that distinguishes the practice of collective bargaining in the United States from that in other nations, is the concept of free collective bargaining. The National Labor Relations Act neither regulates the relationship of the parties once collective bargaining begins, nor specifies any of the substantive terms that must become part of the agreement; in fact, it does not even require that an agreement be reached. ${ }^{73}$ As the Court has said, "Congress intended that the parties should have wide latitude in their negotiations, unrestricted by any governmental power to regulate the substantive solution of their differences." "74 The making of this private law to govern the workplace thus goes forward in private, its provisions not subject to governmental oversight. Consistent with their private character, the overwhelming majority of collective bargaining agreements also provide for a private disputeresolution system, arbitration to settle disagreements about the interpretation and application of these "codes."

There are other misperceptions about the effects of unionization and bargaining that one may carry away from Professor Epstein's piece. Among these are the notions that unionized establishments are less productive $^{78}$ than non-unionized firms and that unions increase wage ine-

(1973).

71. For an elucidation of this view, see id. at 720-24.

72. As Professor Feller observes, "The agreement reached as a result of this bargaining becomes the rule governing the stated portion of the enterprise. It is not an agreement on the terms on which union members will work but an agreement on the rules which management will observe with respect to all employees." Id. at 736. For a brief explication of the incentives management has to accept unions, see id. at 761-71.

73. See, e.g., NLRB v. Insurance Agents Int'l Union, 361 U.S. 477, 488 (1960); NLRB v. American Nat'l Ins. Co., 343 U.S. 395, 401-02 (1952).

74. NLRB v. Insurance Agents Int'l Union, 361 U.S. at 488.

75. Over $95 \%$ of collective bargaining agreements contain provision for arbitration. U.S. Bureau of Labor Statistics, Dep't of Labor Bull. No. 1425-6, Arbitration Procedures (1966).

76. See R. FREEMAN \& J. MEDOFF, supra note 1, at 21-22, 162-80. 
quality ${ }^{77}$ As the latest empirical research demonstrates, these (and a number of other widely held beliefs about the effects of unions) are not true. $^{78}$ This is not to suggest that the authors believe that the Wagner Act was a piece of statutory drafting without peer, or that every aspect of unionization is an unalloyed good. It is to suggest that the NorrisLaGuardia and Wagner Acts, by affording employees the associational rights enjoyed by employers, and the opportunity to participate in setting and administering the terms under which they work, do much to increase individual freedom and decrease authoritarian constraint. ${ }^{79}$ They do so not only in the workplace, but in the political realm as well, through ensuring that employees are free to join groups that can represent their interests in an organized way, just as corporations and business lobbies represent entrepreneurs.

The fact that unions and other mediating groups do not exist or are highly controlled in totalitarian systems of both the right and left is not coincidental. As Derek Bok and John Dunlop point out, unions make an important contribution to the democratic process in a society dominated by large organizations through providing "a coordinated and coherent political voice to workers who would otherwise be largely disorganized," and by increasing "the political participation of poorer segments of society. ..." ${ }^{80}$ In contemplating Professor Epstein's arguments, one does well to regard the outcomes his suggested scheme encourages, and to recall Justice Holmes' acute observation that it is considerations of social advantage, not logic, that determine the configurations of one's legal arguments. ${ }^{81}$

As Archibald Cox has observed, ${ }^{82}$ one of the principal things labor asked of the law was the unfettered right to form, join and assist unions. It is this right that the Norris-LaGuardia Act removed from private determination, through outlawing the yellow dog device. It is this right of free association that the National Labor Relations Act affirmatively guarantees

77. See id. at 20,78-93. Professors Freeman and Medoff observe that the claim that unions increase wage inequality:

is wrong not because the effect to which it directs attention-raising wages of some workers at the expense of other workers-does not occur. It does. The claim is wrong because the increase in inequality induced by monopoly wage effects is dwarfed by three other trade union effects on wages that reduce inequality: union wage policies lower inequality of wages within establishments; union wage policies favor equal pay for equal work across establishments; and union wage gains for blue-collar labor reduce inequality between white-collar and blue-collar workers.

Id. at 78 .

78. See id; S. Slichter, J. HeAly \& E. LIVERnASH, supra note 1.

79. See supra note 67.

80. D. BOK \& J. DUNLOP, LABOR AND THE AMERICAN COMMUNITY 425 (1970). Concerning the strength of unions' political power, see R. FREEMAN \& J. MEDOFF, supra note 2, at 191-206.

81. Vegelahn v. Guntner, 167 Mass. 92, 106 (1896) (Holmes, J., dissenting).

82. A. CoX, Law and the National Labor Policy 2 (1960). 
employees, and which is the Act's cornerstone. This right is one for which blood has been shed and lives placed in jeopardy here and elsewhere. To even suggest removing it on the basis of the sort of argument put forth by Professor Epstein is an affront to all those who struggled to make it a reality. 